\title{
A Collegial Approach In Understanding Leadership As A Social Skill
}

\author{
Prakash Singh, Nelson Mandela Metropolitan University, South Africa
}

\begin{abstract}
Current research indicates that the complexities of organisations require a new focus on collegial leadership and the creation of a sense of community in which leadership is shared. Collegiality forms the backbone of shared leadership. Leadership, as a social skill, makes people respect and follow others and is identified by emotional intelligence (EI) factors such as attitude, confidence, respect for others, and trustworthiness. EI is not a replacement for on the job skills and intelligent task-related logical thinking, but it adds to the variety of skills that enable and empower leaders to develop their employees through the enhancement of their social skills.

A survey was conducted among 474 employees with the purpose of the exploratory study being to determine employees' perceptions of their leaders' social skills. Six social skills formed the basis of this investigation; namely, leadership characteristics, communication, conflict management, relationships, empathy, and trust. Both Pearson $r$ and Spearman $\rho$ indicate that the two variables; namely, the job satisfaction of workers and the social skills of leaders rated by the respondents, are significant and therefore directly related. The findings of this exploratory study confirm that the more satisfied a worker is, the higher a leader's social skills are likely to be. Conversely, the more dissatisfied an employee is, the lower a leader's social skills are likely to be. However, this data must be interpreted in terms of the social skills of leaders as being one of the major factors affecting the job satisfaction of workers.
\end{abstract}

Keywords: Leaders' Social Skills; Collegial Working Environment; Emotional Intelligence; Traditional Management

\section{INTRODUCTION}

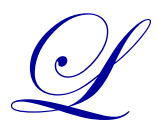

eadership, as a social skill, makes people respect and follow others and is identified by emotional intelligence (EI) factors such as attitude, confidence, respect for others and trustworthiness (Fehd, 2001; Goleman, 2004; Manser, 2005; Singh, 2008; Singh \& Manser, 2008 ). Although the appointment of a leader is considered to be an essential component in the success of an organisation, current research indicates that the complexities of organisations require a new focus on collegial leadership and the creation of a sense of community in which leadership is shared (Retallick \& Fink, 2002; Northouse, 2004). Barth (2006) states that a precondition for doing anything to strengthen our practice and improve an organisation is the existence of a collegial culture in which "professionals talk about practice, share their craft knowledge, and observe and root for the success of one another." He makes it clear that to "promote collegial relationships in the organisation, someone has to make relationships among adults discussable. Someone must serve as a minesweeper, disarming those landmines." (p. 33)

The traditional emphasis on bureaucracy is being challenged by a normative preference for collegiality in many parts of the world (Manz \& Sims, 2001; Kouzes \& Posner, 1997; Kouzes \& Posner, 2001; Bush, 2003; Singh, 2008). Traditional management implies that the "ideal organization is orderly and stable so that the organizational process can and should be engineered so that things run like clockwork" (Kouzes \& Posner, 1997, p. 15). Collegiality, on the other hand, is a collaborative process that entails the devolution of power to workers and other stakeholders in order for them to become an integral part of the leadership process of the organisation that is guided by that organisation's shared vision (Sergiovanni, 1991; Singh, 2008). Collegiality is therefore considered a process of assimilation that involves encouraging personal visions to become part of a shared vision built on synergy (Singh 
\& Manser, 2002). This process is possible because collegial strategies tend to be more lateral or horizontal rather than being vertical and hierarchical, reflecting the view that all stakeholders should be involved in decision-making and "own" the outcome of decisions (Bush, 2003, p. 70). As pointed out by Kouzes and Posner (1997), leaders "know that no one does his or her best when feeling weak, incompetent, or alienated; they know that those who are expected to produce the results must feel a sense of ownership" (p.12).

In order for leaders to make workers feel more fulfilled, Day (2000) asserts that leaders need to ensure they are given opportunities to play participatory roles in the leadership of their organisations. The leader needs to provide the support, preparation and guidance for workers to fulfill such a role. It is aptly pointed out by Yukl (1998) that collegial leadership not only involves leadership behaviours that build willing followers who commit themselves to the organisation's objectives, but it also empowers followers to accomplish these objectives by their becoming leaders in their own fields of expertise. Elmore (2000) shares the belief that effective leadership and successful collaboration allow leaders to bring forth new leaders and they, in turn, create new leaders who all share in the pressures, stresses and rewards of the task at hand. This is not a single-handed undertaking, but a multifaceted challenge that Elmore (2000) predicts could culminate in a strong bond of mutual respect, trust and collaborative bonding. To realise this objective, a collegial working environment is imperative for leadership as a social skill to come to the fore as investigated in this study.

Hellriegel, Jackson, Slocum, Staude, Amos, Klopper, Louw and Oosthuizen (2006) define a manager as "a person who plans, organizes, directs, and controls the allocation of human, material, financial, and information resources in pursuit of the organization's goals" (p. 6). In terms of their definition, a successful manager capably performs four basic managerial tasks: planning, organizing, leading, and controlling. The task of leading involves communicating with and motivating others to perform the tasks necessary to achieve the organization's goals within the context of a supporting organization culture (Hellgriel et al., 2006, p. 9). Hellriegel et al. (2006) note that leadership involves influencing others to act towards the attainment of a goal, and this is based on interpersonal (social) relationships, not administrative activities and directives (p. 286). They believe that individuals throughout the organization can and should exercise leadership and that the best organizations have effective leaders at all levels. They further point out that successful leadership depends on the leader establishing trust, clarifying the direction in which people should be headed, communicating clearly so that people would feel confident that they could make the right decisions, encouraging others to take risks, and, finally, having a source of power which Hellriegel et al. (2006) regard as the ability to influence the behaviour of others (p. 287).

Studies (Cherniss, 2000; Goleman, 2004; Singh, 2008; Singh \& Manser, 2008) in several organizations suggest that about two-thirds of the competencies linked to superior performance are emotional or social qualities such as self-confidence, flexibility, persistence, empathy, and the ability to get along with others. This research data further indicate that in leadership positions, ninety percent of the competencies necessary for success are social and emotional in nature. Healthy and effective relationships, personal leadership, self-management, personal growth and development, and recognition of potential problems are essential elements for creating a positive and healthy working climate (Merkowitz \& Earnest, 2006). Evidently, it is impossible to construe collegial leadership qualities without focusing on EI. Singh and Manser (2002) point out that in order for a collegial environment to flourish for the benefit of all, there need to be opportunities for people to develop their skills. The creation of opportunity cannot flourish in a climate of negativity; therefore, as Millinger (2004) suggests and as the findings of the study confirm, a leader's optimism forms the nucleus of a positive collaborative climate and a collegial environment where a sense of job satisfaction amongst workers is enhanced. The exploratory study analysed in this paper will evoke the importance of collegial leaders' emotionally intelligent behaviours which are shaped by their social skills.

\section{WHY EI?}

EI is not in opposition to IQ (cognition), but according to Stein and Book (1999), it is an extension of the human's potential to succeed in a people-orientated environment. It is also pointed out by Stein and Book (1999) that EI is not the antithesis of IQ, but rather it is a combination of both emotion and cognition. EI is not a replacement for on-the-job skills and intelligent task-related logical thinking, but it adds to the variety of skills that enable a leader to develop people through the enhancement of one's effective leadership skills (Caruso \& Salovey, 2003). It is also suggested by Goleman (1998) that the importance of EI lies in the fact that there are certain 
situations, specifically in the areas of leadership, where EI could be more effective than IQ in terms of personal communication, motivation, self-control and empathetic behaviour. In other words, there are emotional factors that are not IQ related that play a relatively greater role in the acquisition of more favourable outcomes in the workplace when related specifically to relationships. The importance of combining a leader's EI and IQ to create organisational effectiveness and job satisfaction for employees is also supported by Caruso (1999) and is clarified by the following definition:

EI is the ability to use emotions to help you solve problems and live a more effective life. Emotional intelligence without intelligence, or intelligence without emotional intelligence, is only part of a solution. The complete solution is the head working with the heart (p. 26).

As pointed out by Caruso (1999), this suggests that all people receive and transfer emotional information and that one can choose to ignore this information or react in a destructive or an intelligently constructive way. In order to choose appropriate actions, the personal or social emotional grammar needs to be interpreted correctly. One's EI will determine the appropriateness of one's competency which is regarded by Bar-On (2000) as an array of non-cognitive capabilities, competencies and skills that influence one's ability to succeed in coping with environmental demands and pressures. Consequently, the level of emotional behaviour demonstrated determines one's emotional competencies, which Goleman (1998) defines as those learned capabilities based on EI that are evident in outstanding performances at work (p. 24). This is further highlighted by Bar-On (2000) in the following definition of EI:

Emotional and social intelligence is a multi-factorial array of interrelated emotional, personal and social abilities that influence our overall ability to actively and effectively cope with daily demands and pressures (p. 96).

Orme and Bar-On (2002) contend that there is a close similarity between EI and social intelligence and they suggest that the two concepts should be regarded as being synonymous and referred to as emotional and social intelligence and that the definitions for both should be combined into the following basic competencies or abilities:

- $\quad$ the ability to understand and express emotions constructively

- $\quad$ the ability to understand others' feelings and establish cooperative interpersonal relationships

- $\quad$ the ability to manage and regulate emotions in an effective manner

- $\quad$ the ability to cope realistically with new situations and to solve problems of a personal and interpersonal nature as they arise

- $\quad$ the ability to be sufficiently optimistic, positive, and self-motivated in order to set and achieve goals (p. 23)

These are not innate competencies; therefore, according to Orme and Bar-On (2002), they can be learned.

The four cornerstones model of EI presented in Figure 1 is based on the premise that individuals should learn to trust in their own abilities and listen to, what Cooper and Sawaf (1997, p. xxvi) refer to as gut hunches, when important decisions need to be made:

The four cornerstones model moves EI out of the realm of psychological analysis and philosophical theories and into the realm of direct knowing, exploration, and application.

The first cornerstone described by Cooper and Sawaf (1997) uses, as its building blocks, concepts such as the emotional honesty, emotional energy, emotional feedback, and intuition. The second strengthens authenticity, credibility, and resilience, which, according to Cooper and Sawaf, expands one's circle of trust, capacity for listening, and helps one manage conflict. The third cornerstone suggests ways that one can work with one's unique potential and purpose and to strengthen this with integrity, commitment, and accountability. Finally, the fourth cornerstone described by Cooper and Sawaf is linked to creativity, common sense, and untapped opportunities. This model suggests that there is a wide scope for both leaders and their workers to develop their emotionally intelligent skills in the workplace. The four cornerstones and their related concepts are closely linked to collegial leadership that can enhance job satisfaction for workers. 


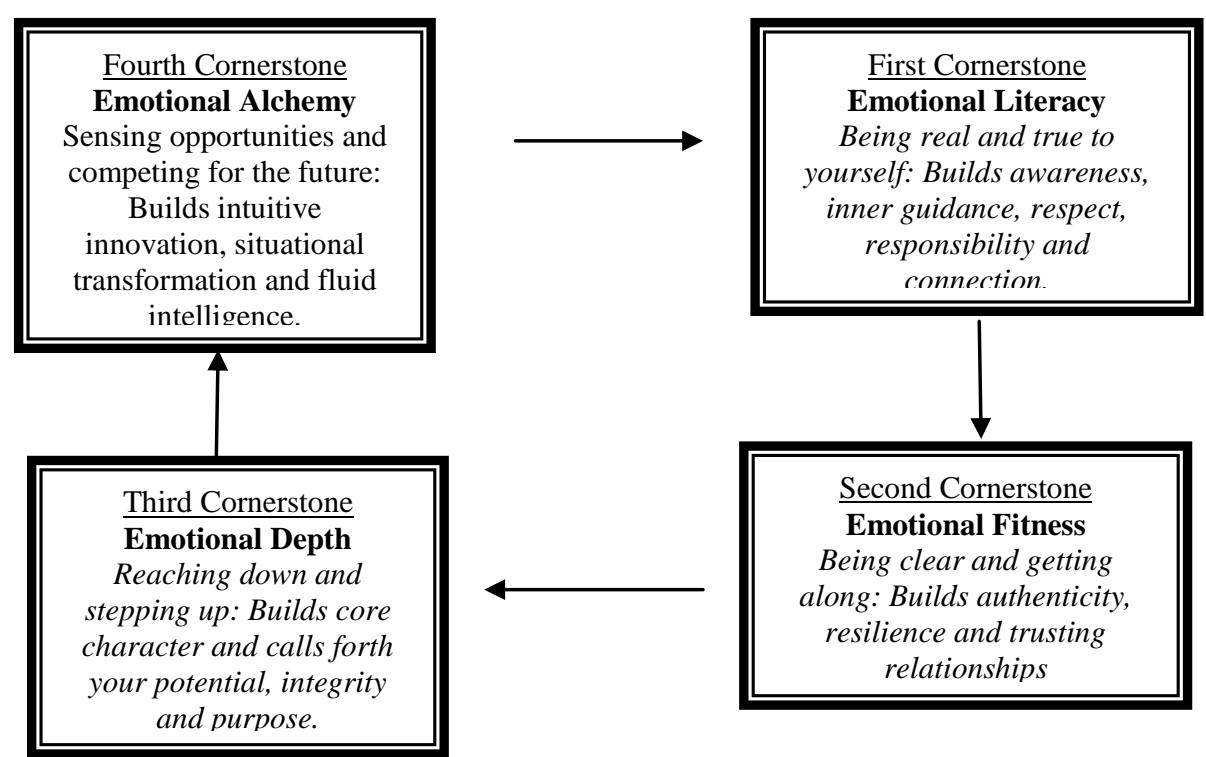

Figure 1: The Four Cornerstones Of EI

\section{EI AND SHARED LEADERSHIP IN A COLLEGIAL ENVIRONMENT}

Leadership structures need to be changed or adapted by leaders so that, as Pauw and Kok (2002, p. 6) argue, workers are able to make a meaningful contribution as leaders and experts in a manner that makes full use of the human potential available as an organization. According to Covey (2004, p. 4), changes that need to be made to leadership structures should not be thought of as an event, but rather as a process of development, change, and adaptation. Part of the process of adaption is inspired by what Covey (2004, p. 5) refers to as an eighth habit identified as the voice of the human spirit. This is described by Covey (2004) as a timeless reality that encompasses the soul of an organization that becomes an integral part of development, change and, ultimately, passionate involvement in an organization:

When you engage in work that taps your talent and fuels your passion that arises out of a great need in the world that you feel drawn by conscience to meet, therein lies your voice, your calling, your soul's code (p. 7).

Preconceptions regarding expected behaviour and roles of leaders need to be altered in order to facilitate the concepts of shared decision-making, shared leadership, and transformational thinking (Covey, 2004; Singh, 2008). The more collegial the leadership structure is coupled with a high degree of trust, the more likely it will be that holonomy will result and the goals of collegiality will be met (Manser, 2005). In order to increase levels of fulfillment, Garmston and Wellman (1995, p. 134) claim that individual workers should be able to act autonomously in an organization, while at the same time being part of the organisation's staff that is working interdependently. This gives rise to the term holonomy or autonomous interdependence, which may seem to be an oxymoron, but the aim is to transcend these terms of being an individual who acts as a participant within the organization (Manser, 2005).

The importance of interpersonal engagement in the development of a community structure is further supported by Stahl (2000) who cites a study sponsored by the American Management Association. The study claims that the values and characteristics most admired by the 1,500 respondents were integrity, competence, and leadership. These competencies were also identified as the ones most likely to be adversely affected if the leader did not display passion, energy, and a positive attitude about the workplace. According to Stahl (2000), a high staff turnover is experienced in institutions where leaders convey negative feelings to their staff as their sense of meaningful collaboration and sincere community identity were questioned. Workers need to feel that they are able to make meaningful input as individuals and at the same time help create a common goal for their organisations, in 
general, without fear of reprisal from their leaders (Singh \& Manser, 2002; Northouse, 2004; Singh \& Manser, 2008). Goleman (1998) purports that in an emotionally intelligent organisation, leadership should be collaborative, transformational and based on shared objectives because these are the keys to good performance:

The interpersonal skills and compatibility of the group members emerged as key to their performance. When teams operate at their best, they can be more than simply additive - they can be multiplied. In other words, the best talents of one person catalyses the best of another and another... for when a team has synergy, its score far outweighs the best individual score (p. 205).

In an examination of the relationship between EI and effective shared leadership, Gardiner and Stough (2002) predict that there will be a strong relationship between high EQ and strength of leadership. They also point out that there are significant correlations between the EI of leaders and the emotional demands made on them:

The ability to manage and monitor emotions within oneself and others correlated with the inspirational motivation and individualized consideration components of transformational leadership. Second, the ability to monitor emotions within oneself and others correlated significantly with the transformational leadership components of idealised attributes and idealised behaviours (p. 71).

The results of a study conducted at the University of Queensland presented by Ashkanasy and Dasborough (2003) support the view that emotions play a potentially important role in the understanding of organisations. The findings suggest that there is a need to teach the importance of emotions in a leadership course. According to Ashkanasy and Dasborough (2003), the study revealed that teaching about emotions and EI could affect a team's performance because the members of the team had a greater understanding about themselves and the members of their team. An integral part of leadership, therefore, needs to concentrate on the development of EI in order for development to take place in an atmosphere of mutual understanding, trust, and self-confidence. As aptly pointed out by Maryl, Hardin, Olibas, Rodgers and Spiller (2004), the confidence displayed should reveal the leader's sense of self-confidence, the leaders' confidence in the group's abilities, the group's confidence in the leader, and the group's confidence in its own abilities. Such confidence is described by Maryl et al. (2004) as the way in which workers and leaders share common values, goals, accountability, and a sense of trust built on a foundation of collegiality. According to Singh (2005), the objectives of shared leadership and collegiality should help create an enabling environment which is guided by that organisation's shared vision and mission statement. This also signifies that a sense of job satisfaction could be associated with the demonstration of professional behaviour toward colleagues based on attitudes and virtues that are also evident in the organisation's shared vision and mission statement (Ihara (1998).

If a leader supports the development of a collegial organisation environment that advocates shared leadership, then the leader's EI is an important contributor to the attainment of such an environment (Gardiner \& Stough, 2002). One way to cater to the needs of a workforce is described by Landy (1985) as the creation of enriched jobs which are seen to help create self-motivated workers who love their jobs. Middlewood (2003) points out that McGregor's theory X and theory Y highlight the need to view all employees in a positive light (theory Y) rather than from a negative perspective (theory $\mathrm{X}$ ). Therefore, a collegial environment plays a crucial role in the improvement of efficiency and effectiveness in organizations as decisions, that are imposed rather than attained through a process of consensus, could be regarded as unethical and therefore demotivate workers who do not support the decisions made (Singh, 2005). This could result in an organization becoming less efficient, less effective and therefore less productive (Williams, 1989; Singh, 2008).

Conflict management social skills develop the capacity of leaders to resolve conflict and to minimize unresolved issues that can damage interpersonal relationships with their workers and undermine organizational effectiveness. Also, high levels of EI can help leaders avoid potential destructive and inappropriate conflict with their employees. As pointed out by Fehd (2001, p. 14), a leader can support without agreement and turn potential conflict into collaborative consensus that can lead to creative thinking and innovative change in the organisation. Relationship management is directly proportional to our awareness and use of EI skills (Fehd, 2001). The relationship between leaders, workers, customers and partners is integral to the success of an enterprise. Emotional savvy of leaders is dependent upon their ability to build and sustain rapport with their employees. Being interested in 
people, their families and their beliefs enhance this. An emotionally intelligent leader with social skills will listen to others and give them uninterrupted communication time in a collegial environment (Manser, 2005; Singh, 2008). This process is a major contributory factor in the job satisfaction of workers (Singh \& Manser, 2008).

\section{MOTIVATION AND JOB SATISFACTION}

Yun (1998) contends that there seems to be little doubt that organizations that have sustained success are those that manage to motivate their people effectively. These organizations are able to utilize the potential of their human resources by recruiting the most suitable candidates, equipping them through a relevant induction program, and motivating them to work at optimum performance levels. In order to motivate their workers effectively, Weber (2004) suggests that collegial leaders need to be made aware that they should understand what the needs of workers are and then ascertain what motivates them to become satisfied at work. Weber (2004) adds that leaders also need to recognize how they themselves are motivated and driven in their personal and professional lives in order to master their personal leadership to successfully lead and motivate others. According to Hilliard (1995), social (interpersonal) intervention strategies and people-oriented approaches stress that improved performance is dependent on the leadership style and the quality of leadership that is practised in an organisation. Incentives that are based on morals and values are described by Propenko (1987) as being the most effective for employees who wish to gain praise from employers or to gain respect from employers and fellow workers.

According to Johns (1996), motivation may be either intrinsic, extrinsic or both, but in order for stimuli to be regarded as successful motivators, they need to inspire a collection of attitudes that employees have about their work which determines whether they are satisfied at work or not. As pointed out by Khol (2004), this means that the leader needs to assume the role of an advocate in order to motivate, and, in so doing, support, defend and embrace those being led. Reichheld (2001) suggests that catering to the workers' intrinsic needs creates a sense of loyalty to the organization and encourages the building of successful, mutually valuable relationships. Of the motivational strategies that exist, extrinsic, incentive, and reward schemes seem to be widely accepted as effective motivational tools, both in the private and public sector; but according to Lethoko (2004), achievement motivation becomes a dominant concern in organizations. He further states that workers who are committed to their task have a drive to achieve excellence, get ahead, improve on past performances, and find unique solutions to difficult problems. In other words, they are intrinsically achievement-driven.

Although profit-sharing schemes and monetary rewards are widely used as a means to motivate staff, Kouzes and Posner (1995) assert that extrinsic rewards are not the only incentive schemes that motivate an employee to improve performance. They argue that if external rewards are successful in motivating employees, then the question needs to be asked as to why it is necessary for leaders to concern themselves with intrinsic rewards. Regarding this issue, Kouzes and Posner (1995) believe that if "work comes to be seen solely as a source of money and never as a source of fulfilment, organisations will totally ignore other human needs at work - needs involving such intangibles as learning, self-worth, pride, competence, and serving others". They add that "work comes from the inside out; work is an expression of our soul, our inner being" and without "employing peoples' hearts, organizations lose precious returns on their investment in people" (p. 41).

\section{RESEARCH DESIGN}

The quantitative research method was used to determine the employees' perceptions of their leaders' social skills in terms of their emotional intelligence and collegial leadership traits. A sample of 474 employees from 200 organizations participated in this study. The subjects chosen to participate in the study were selected following a process described by McMillan and Schumacher (2001) as nonprobability convenience sampling because the group of subjects was selected on the basis of their accessibility and availability in South Africa (Manser, 2005). A multirespondent survey design was used. In such a design, the focus is on relationships between and among variables in a single group (Robson, 2002; Manser, 2005; Singh \& Manser, 2008). Section A of the survey focused on the demographic variables of the participants while section B collected data on their job satisfaction. In section C, the questionnaire identified six (C1-C6) social skills that the respondents' employers should possess as collegial leaders - leadership (C1), communication (C2), conflict management (C3), relationships (C4), empathy (C5), and trust (C6). 
The 55 questions posed asked the respondents to rate their leaders according to the strength of the observable social EI characteristics in a collegial environment. The value of Cronbach's Alpha was used to determine the reliability of the research; it verified that the research was reliable, that the questionnaire was consistent, and that the scores had insignificant error. The score of 0.923 was regarded as significant. Also, in order to ensure the content and construct validity of the questionnaire, a study of relevant literature on EI was undertaken. There is a similarity that exists between the social EI skills described by Fehd (2001), the scales of emotional intelligence presented by Bar-On (2000), and the five dimensions of EI designed by Goleman (1998).

\section{RESULTS}

Six social skills (C1-C6) were investigated in this study. Based on the 474 respondents' perceptions, they were asked to rank their leaders according to the characteristics given for each of the social skills that their leaders demonstrate. This provides an indication of whether the respondents' leaders are rated as being either strong or weak in each of the social behaviours. A descending order of rank scores, which represent the organisation leaders' social skills, is presented in Table 1.

Table 1: Descending Order Of Leaders' Social Skills

\begin{tabular}{|l|l|c|c|}
\hline Ranking & Social skills & High Ranking Responses (N=474) & \% High Ranking Responses \\
\hline 1 & Communication (C2) & 353 & 74,5 \\
\hline 2 & Relationships (C4) & 337 & 71,1 \\
\hline 3 & Trust (C6) & 327 & 69 \\
\hline 4 & Leadership (C1) & 309 & 65,2 \\
\hline 5 & Empathy (C5) & 290 & 61,2 \\
\hline 6 & Conflict management (C3) & 72 & 15,2 \\
\hline
\end{tabular}

Of the 474 respondents in the study, 309 ranked their leaders as being high (strong) in the leadership behaviour (C1) and 165 ranked their leader as being low (weak) in this behaviour. The second social skill displayed by leaders; namely, their communication behaviour, is measured in $\mathrm{C} 2$. Of the total number of respondents, 353 ranked their leaders as being high (strong) in this behaviour and 121 ranked their leader as being low (weak). Of all the respondents, 72 ranked their leaders as being high (strong) in the conflict management behaviour (C3) and 402 ranked their leader as being low (weak). Of the total number of respondents, 337 of them ranked their leaders as being high (strong) in the relationship behaviour (C4) and 137 ranked their leader as being low (weak). In the empathy behaviour (C5), 290 of the respondents ranked their leaders as being high (strong) and 184 ranked their leader as being low (weak). C6 measured the leader's trustworthiness, which is the sixth and final social skill. There were 327 of the respondents who ranked their leaders as being high (strong) in the trustworthiness behaviour (C6) and 147 ranked their leader as being low (weak).

\section{Correlation Between Job Satisfaction (B) And Social Skills (C1-6)}

Two measures of relationship were used in this study; namely, the Pearson Product - Moment Correlation (r) and Spearman Rank ( $\rho$ or rho). The calculation of $r$ is to show the linear relationship between any two variables. According to Huysamen (1997), the calculation of $r$ and $\rho$ provides an objective measure of the strength of the relationship between the two variables. The level of significance for a two-tail test is 0.01 . It is pointed out by McMillan and Schumacher (2001) that the degree to which subjects maintain the same relative position on any two measures is shown by $\rho$.

Table 2 presents the Pearson Correlation Coefficients $(r)$ of the variables - job satisfaction (B) and all of the social skills (C1-C6). According to Huysamen (1997), the positive relationship indicated in Pearson's $r$ @ $<<0.01$ is significant. The Pearson Correlation values are greater than zero, indicating a positive correlation between the social skills and the job satisfaction of workers. When there is an increase in C, B will also increase. This indicates that a significant relationship exists amongst the variables; namely, the social skills of organisation leaders (C) and the job satisfaction of workers (B). For example, the Pearson correlation between C4 (relationships behaviour) and B (job satisfaction) is 0,537 with a highly significant $p$-value of 0 , which is less than 0,01 . Of the total number of respondents, 337 of them ranked their leader as being high (strong) in the relationship behaviour and 137 ranked 
their leader as being low (weak). This indicates that a significant relationship exists between $\mathrm{C} 4$ and $\mathrm{B}$, hence suggesting quite a strong relationship between the relationship behaviour $(\mathrm{C} 4)$ of the leader and the job satisfaction of workers (B) in a collegial work environment.

Table 2: Pearson Correlation Coefficients for B and C1-6

\begin{tabular}{|c|c|c|c|c|c|c|c|c|}
\hline & & B & C1 & $\mathbf{C 2}$ & C3 & C4 & C5 & C6 \\
\hline \multirow[t]{3}{*}{$\mathrm{B}$} & Pearson Correlation & 1 & $.560^{* * *}$ & $.538^{* *}$ & $.288^{* * *}$ & $.537^{* * *}$ & $.556^{* * \pi}$ & $.574^{* * \pi}$ \\
\hline & Sig. (2-tailed) & .000 & .000 & .000 & .000 & .000 & .000 & .000 \\
\hline & $\mathrm{N}$ & 474 & 474 & 474 & 474 & 474 & 474 & 474 \\
\hline \multirow[t]{3}{*}{$\mathrm{C} 1$} & Pearson Correlation & $.560^{* * *}$ & 1 & $.588^{* *}$ & $.309^{* *}$ & $.599^{* * *}$ & $.681^{* * *}$ & $.611^{* * *}$ \\
\hline & Sig. (2-tailed) & .000 & .000 & .000 & .000 & .000 & .000 & .000 \\
\hline & $\mathrm{N}$ & 474 & 474 & 474 & 474 & 474 & 474 & 474 \\
\hline \multirow[t]{3}{*}{$\mathrm{C} 2$} & Pearson Correlation & $.538^{* *}$ & $.588^{* *}$ & 1 & .248 & $.662^{* *}$ & $.636^{* * *}$ & $.664^{* *}$ \\
\hline & Sig. (2-tailed) & .000 & .000 & .000 & .000 & .000 & .000 & .000 \\
\hline & $\mathrm{N}$ & 474 & 474 & 474 & 474 & 474 & 474 & 474 \\
\hline \multirow[t]{3}{*}{$\mathrm{C} 3$} & Pearson Correlation & $.288^{* *}$ & $.309^{* * *}$ & $.248^{* * *}$ & 1 & $.244^{* * *}$ & $.337^{* * *}$ & $.258^{* * *}$ \\
\hline & Sig. (2-tailed) & .000 & .000 & .000 & .000 & .000 & .000 & .000 \\
\hline & $\mathrm{N}$ & 474 & 474 & 474 & 474 & 474 & 474 & 474 \\
\hline \multirow[t]{3}{*}{$\mathrm{C} 4$} & Pearson Correlation & $.537^{* *}$ & $.599^{* *}$ & $.662^{* * *}$ & .244 & 1 & $.705^{* * *}$ & $.659^{* * *}$ \\
\hline & Sig. (2-tailed) & .000 & .000 & .000 & .000 & .000 & .000 & .000 \\
\hline & $\mathrm{N}$ & 474 & 474 & 474 & 474 & 474 & 474 & 474 \\
\hline \multirow[t]{3}{*}{$\mathrm{C5}$} & Pearson Correlation & $.556^{* * *}$ & $.681^{* * *}$ & $.636^{* * *}$ & .337 & $.705^{* * *}$ & 1 & $.739^{* * 6}$ \\
\hline & Sig. (2-tailed) & .000 & .000 & .000 & .000 & .000 & .000 & .000 \\
\hline & $\mathrm{N}$ & 474 & 474 & 474 & 474 & 474 & 474 & 474 \\
\hline \multirow[t]{3}{*}{ C6 } & Pearson Correlation & $.574^{* *}$ & $.611^{* * *}$ & $.664^{* * *}$ & .258 & $.659^{* *}$ & $.739^{* *}$ & 1 \\
\hline & Sig. (2- tailed) & .000 & .000 & .000 & .000 & .000 & .000 & .000 \\
\hline & $\mathrm{N}$ & 474 & 474 & 474 & 474 & 474 & 474 & 474 \\
\hline
\end{tabular}

Correlation is significant at the 0.01 level (2-tailed)

Table 3 presents the findings of the Spearman Rank Correlation ( $\rho$ or rho) used to show the symmetric measures and the relationships between the variables job satisfaction (B) and the six social skills (C1-6). According to Huysamen (1997), the positive relationship indicated in Spearman's @ p $<0.01$ is significant. The Spearman's correlation values are greater than zero indicating a positive correlation between the variables. This indicates that a significant relationship exists amongst the variables. The correlation between C3 (conflict management) and C1 (leadership) is .309 with a highly significant p-value of 0 which is less than 0,01 . This indicates that a significant relationship exists between $\mathrm{C} 3$ and $\mathrm{C} 1$. The Pearson correlation between C6 (trust) \& C5 (empathy) is 0,739 with a highly significant $\mathrm{p}$-value of 0 which is less than 0,01 . This indicates that a significant relationship exists between C6 and C5. There is a large correlation between C3 and C4 suggesting a strong relationship between conflict management and the relationship behaviour of the leader.

Table 3: Spearman's Correlation Coefficients for B and C1-6

\begin{tabular}{|c|c|c|c|c|c|c|c|c|}
\hline & & B & C1 & C2 & C3 & C4 & C5 & C6 \\
\hline B & $\begin{array}{l}\text { Correlation Coefficient } \\
\text { Sig. (2-tailed) } \\
\text { N }\end{array}$ & $\begin{array}{c}1 \\
.000 \\
474\end{array}$ & $\begin{array}{l}.560^{* *} \\
.000 \\
474\end{array}$ & $\begin{array}{l}.538^{* * *} \\
.000 \\
474\end{array}$ & $\begin{array}{l}.288^{* * *} \\
.000 \\
474\end{array}$ & $\begin{array}{l}.537^{* *} \\
.000 \\
474\end{array}$ & $\begin{array}{l}.556^{* * *} \\
.000 \\
474\end{array}$ & $\begin{array}{l}.574^{* *} \\
.000 \\
474\end{array}$ \\
\hline $\mathrm{C} 1$ & $\begin{array}{l}\text { Correlation Coefficient } \\
\text { Sig. (2-tailed) } \\
\text { N }\end{array}$ & $\begin{array}{l}.560^{* * *} \\
.000 \\
474\end{array}$ & $\begin{array}{c}1 \\
.000 \\
474\end{array}$ & $\begin{array}{l}.588^{* * *} \\
.000 \\
474\end{array}$ & $\begin{array}{l}.309^{* * *} \\
.000 \\
474\end{array}$ & $\begin{array}{l}.599^{* * *} \\
.000 \\
474\end{array}$ & $\begin{array}{l}.681^{* * *} \\
.000 \\
474\end{array}$ & $\begin{array}{c}.611^{* * * * * 6} \\
.000 \\
474\end{array}$ \\
\hline $\mathrm{C} 2$ & $\begin{array}{l}\text { Correlation Coefficient } \\
\text { Sig. (2-tailed) } \\
\text { N }\end{array}$ & $\begin{array}{l}.538^{* * *} \\
.000 \\
474\end{array}$ & $\begin{array}{l}.588^{* *} \\
.000 \\
474\end{array}$ & $\begin{array}{c}1 \\
.000 \\
474 \\
\end{array}$ & $\begin{array}{l}.248^{* * *} \\
.000 \\
474\end{array}$ & $\begin{array}{c}.662^{* * *} \\
.000 \\
474\end{array}$ & $\begin{array}{l}.636^{* *} \\
.000 \\
474\end{array}$ & $\begin{array}{l}.664^{* *} \\
.000 \\
474\end{array}$ \\
\hline C3 & $\begin{array}{l}\text { Correlation Coefficient } \\
\text { Sig. (2-tailed) } \\
\text { N }\end{array}$ & $\begin{array}{l}.288^{* * *} \\
.000 \\
474\end{array}$ & $\begin{array}{l}.309^{* *} \\
.000 \\
474\end{array}$ & $\begin{array}{l}.248^{\text {** }} \\
.000 \\
474\end{array}$ & $\begin{array}{c}1 \\
.000 \\
474\end{array}$ & $\begin{array}{l}.244^{* * *} \\
.000 \\
474\end{array}$ & $\begin{array}{l}.337^{* *} \\
.000 \\
474\end{array}$ & $\begin{array}{l}.258^{* *} \\
.000 \\
474\end{array}$ \\
\hline $\mathrm{C} 4$ & $\begin{array}{l}\text { Correlation Coefficient } \\
\text { Sig. (2-tailed) } \\
\text { N }\end{array}$ & $\begin{array}{l}.537^{\text {*** }} \\
.000 \\
474 \\
\end{array}$ & $\begin{array}{l}.599^{* *} \\
.000 \\
474 \\
\end{array}$ & $\begin{array}{l}.662^{* * *} \\
.000 \\
474\end{array}$ & $\begin{array}{c}.244^{* * * * * * *} \\
.000 \\
474\end{array}$ & $\begin{array}{c}1 \\
.000 \\
474 \\
\end{array}$ & $\begin{array}{l}.705^{* * *} \\
.000 \\
474 \\
\end{array}$ & $\begin{array}{l}.659^{* *} \\
.000 \\
474 \\
\end{array}$ \\
\hline
\end{tabular}




\begin{tabular}{|l|l|c|c|c|c|c|c|c|}
\hline C5 & Correlation Coefficient & $.556^{* *}$ & $.681^{* *}$ & $.636^{* *}$ & $.337^{* * *}$ & $.705^{* *}$ & 1 & $.739^{* * *}$ \\
& Sig. (2-tailed) & .000 & .000 & .000 & .000 & .000 & .000 & .000 \\
& $\mathrm{~N}$ & 474 & 474 & 474 & 474 & 474 & 474 & 474 \\
\hline C6 & Correlation Coefficient & $.574^{* *}$ & $.611^{* *}$ & $.664^{* *}$ & $.258^{* * *}$ & $.659^{* *}$ & $.739^{* *}$ & 1 \\
& Sig. (2- tailed) & .000 & .000 & .000 & .000 & .000 & .000 & .000 \\
& $\mathrm{~N}$ & 474 & 474 & 474 & 474 & 474 & 474 & 474 \\
\hline
\end{tabular}

Correlation is significant at the 0.01 level (2-tailed)

The correlation coefficients given in Tables 2 and 3 clearly show that the bivariate distribution of the variables has a positive and direct relationship. Both Pearson $r$ and Spearman $\rho$ indicate that the two variables; namely, the job satisfaction of workers and the social skills of a leader rated by the respondents, are significant and therefore directly related. In other words, the findings of this study confirm that the more satisfied a worker is, the higher a leader's social skills are likely to be. Conversely, the more dissatisfied an employee is, the lower a leader's social skills are likely to be. However, this data must be interpreted in terms of the social skills of leaders as being one of the major factors affecting the job satisfaction of workers. The noticeable exception is the low positive value for C3 (a leader's ability to handle conflict). However, there is no objective explanation for this particular social skill to be so different from the rest in this study.

\section{Correlation Between B And C1}

The significant correlation between a worker's sense of job satisfaction (B) and a leader's leadership characteristics (C1) indicates that a leader's demonstration of emotionally intelligent leadership behaviour will enhance a worker's sense of job satisfaction. Also supported by the findings is the view expressed by Burbach, Barbuto and Wheeler (2003) that a people-centred leadership approach is essential for effective leadership characteristics to be meaningful for the attainment of workers' job satisfaction. The leader's role as a catalyst for constantly maintaining a common purpose and a team-focused approach, as suggested by Gardiner and Stough (2002), is significant, particularly when the leader is viewed by the workers as the inspirer and the motivator.

\section{Correlation Between B And C2}

The view held by McCann (2000) that in a climate that enhances a worker's sense of job satisfaction, a leader needs to be approachable and easy to talk to, is supported by the symmetric measures which reveal a meaningful correlation between job satisfaction and the ability of a leader to communicate (C2) effectively. The concept of a leader as a people-person, who has managed to move away from a task-orientated, top-down approach and create a collegial environment that emphasises the importance of people, is supported. According to Goleman (1998), good communicators in leadership positions have an ability to chastise in such a way that people come away feeling good about themselves. They are able to socialise and enter into discussions in a non-aloof or threatening way.

Workers feel comfortable in the company of a leader who is able to communicate meaningfully with them and sense that they are able to speak their mind without fear of reprisal (Goleman, 1998). Such leaders see the need to be person-centred when the situation requires it. They are able to accurately judge a situation and make appropriate comments at opportune times. The leader keeps the organisation community informed and supplies as much information as possible, as often as possible. The attainment of what Garmston and Wellman (1995) refer to as holonomy and the establishment of a harmonious coexistence, are enhanced by a leader's emotionally intelligent communicative behaviour. Participation in decision-making is not contrived and neither are outcomes predetermined; but as Lee (2005) suggests, leadership is sincere and charismatic and consensus is a reality rather than a mere rubber stamp. In such a climate, the findings reveal that a leader's effective communication is perceived as being a social skill that enhances a worker's sense of job satisfaction.

\section{Correlation Between B And C3}

The fact that all respondents who are dissatisfied at work indicated that their leaders manage conflict badly shows that there is a significant correlation between job dissatisfaction and a leader's inability to manage conflict (C3). Leaders need to be aware that this is an area of their leadership that needs attention. As suggested by Mertler 
(2002), effective conflict resolution and conflict management are areas of leadership that form a fundamental part of a collegial community. A leader who demonstrates a willingness to deal with conflict finds it appropriate to apologise when in the wrong, yet, as suggested by Gazzard (2002), is non-threatening when dealing with potential conflict situations with others. There should be a sense of confidence in workers that when conflict does arise, the leader is there to act as a mediator. Conflict management is an area that cannot be ignored when leaders engage in the development of their social skills.

\section{Correlation Between B And C4}

The influence of a leader's ability to build healthy relationships (C4) - which is the fourth social skill - and the attainment of job satisfaction also has a significant correlation. The findings indicate that a leader's ability to build healthy relationships with his/her workers is also important for ensuring that workers experience a sense of job satisfaction. The word healthy refers to the professional nature of the relationships that should be nurtured and developed in order to satisfy what Sterrett (2000) identifies as the needs of workers on the one hand and the fulfilment of the objectives of the organisation on the other. A leader's ability to do this is rated as an important social skill by workers and one that clearly enhances an intense feeling of job satisfaction. Whitaker (2001) believes that a leader's ability to recognise and develop skills in others and assist people to reach their true potential is integral to the development of meaningful relationships in a spirit of teamwork and collaboration, are supported by the findings. Also supported by the findings is the belief expressed by Strümpfer and Mlonzi (2001) that leaders need to have an understanding of workers' emotional limitations, as well as their own, in order to create working relationships that complement each other and have a positive effect on the organisational effectiveness of the organisation. The workers view the leaders' ability to recognise the meanings of emotions in others and then to act accordingly as being integral to the development of healthy relationships. This view is supported by McCann (2000) who suggests that the greater the leader's ability to engage with and make full use of the strengths of the human resources available at the organisation, the more noticeable the social skills become.

The creation of job satisfaction and the development of healthy working relationships are integral to the success of any organisation. Closely linked to the creation of professional relationships is the concept of collegiality. The link between each of the social skills is a people-centred approach to leadership, which Pauw and Kok (2002) argue, ensures that workers make a meaningful contribution to the organisation. Leaders who fear that their control will diminish if they open themselves to a shared accountability need to be assured that their respect of others' talents and their appreciation of their skills will result in a more satisfied staff because, as Maryl et al. (2004) suggest, they will appear to be more self-confident rather than self-preserving. Ihara (1998) points out that the leader's role of coach and facilitator of teams will build respect because of their professional behaviours and therefore leaders need not fear that they will be frowned upon for a perceived abdication of responsibility. A leader who utilises and maximises the human resources available by making leadership roles available to workers demonstrates what Day (2000) identifies as a strong sense of relationship development by providing relevant learning opportunities. In the current climate of flux and change, Strümpfer and Mlonzi (2001) maintain that it is essential that leaders identify with the concerns of workers. The development of professional relationships creates opportunities for leaders and workers to share concerns and to solve the problems together.

\section{Correlation Between B And C5}

The fifth social skill is empathy (C5). Once again, it is apparent that there is a strong correlation between a leader's demonstration of empathy and the job satisfaction of the workers. A leader's demonstration of empathy is, according to Calitz (2002), directly related to the ability to work with, understand and react accordingly to the emotional grammar of workers. The findings concur with Vermeulen (1999) who recommends that leaders need to be able to identify the signs which indicate when individuals are in various states of emotion and then help them to deal with the situation if deemed necessary.

The social skill of empathy relies on the ability of a leader to nurture workers through caring, understanding and concern. There is a sensitivity that is required that will help individuals feel that they are sincerely cared for and important enough to be understood and accepted and, in this way, as Maile (2000) suggests, help them cope with stress. Clearly, a collegial environment that nurtures empathy is a people-centred one rather than a hierarchical structure that concentrates more on power bases than people (Singh, 2005). 
Workers clearly indicated that they need to be led with confidence and in order for this to occur, they require a leader to understand their needs and emotional strengths and weaknesses. Empathy will flourish in an organisation that Singh (2005) describes as one that stresses the importance of lateral relationships and the decentralisation of power because, as Moller (2002) points out, those who are willing to lead need to be identified and empowered and those who are not deserve the same amount of empathetic understanding. Also, Goleman (1996) points out that an empathetic leader is one that encourages accountability and responsibility on the one hand and does not criticise failure on the other. Fear of failure is not a by-product of an empathetic leader because, as Goleman (1996) aptly points out, with empathy comes concern and sensitivity. These emotions are not present at the expense of efficiency but rather serve to enhance the effectiveness of the organisation.

\section{Correlation Between B And C6}

Trustworthiness refers to a leader's ability to actively place trust (C6) in others and, conversely, their ability to trust him/her. In a collegial environment, Gaziel (2003) maintains that it is essential that a leader is able to trust others who have been given the opportunity to take the lead in various portfolios or projects in the organisation and that they find him/her worthy of their trust. The significant correlation between trustworthiness and job satisfaction is compatible with the views of Wasserstein-Warnett (2000) that to trust comes the added responsibility and a feeling that one is relatively free to develop and grow without fear of failure. As Gaziel (2003) points out, in order to be trusted, the leader needs to demonstrate trust. Self-efficacy cannot be achieved where individuals are not trusted and then entrusted with tasks.

In order for a leader to be trusted, trustworthiness needs to be developed over a period of time (Goleman, 1996). It can quickly be broken and is therefore perceived as a fickle emotional state, which Goleman maintains is one that can be built through reliability and authenticity. Where there is no trust, there will be little support and a great deal of suspicion. Standards of honesty and integrity need to be maintained and a leader needs to be above reproach. It is therefore understandable that a leader's trustworthiness is an essential component of a worker's sense of job satisfaction. According to Elmore (2000), the members of a collegial team will need to be able to trust that the leader is supportive of their efforts and their input is regarded as meaningful. If such trust does not exist, there will be little chance of successful collaboration in an environment where sincerity is viewed with suspicion and doubt.

A worker's association with, and a belief in the organization's core values, may not be enough to instill trust. Linked to what Singh (2005) defines as the essential foundation of a collegial environment, the leader must also share the same values and offer the same support to all in order for there to be a sense of identity and trust to develop. The creation of trust is a process that is forged over time. A leader must demonstrate an honest endeavour to develop effective and passionate leadership skills in a collegial environment, encourage sincere communication, practice precise and fair conflict management, develop healthy relationships, cultivate an empathetic understanding of how to identify and handle the emotions of colleagues, and then in the most meaningful and sincere manner as possible, trust others and be trusted by them.

\section{CONCLUSION}

Being a leader requires the person to promote an organizational passion for quality. It is a myth that leaders are entrusted with absolute power to manage all the resources of the organisation. Collegiality forms the backbone of shared leadership. It is about sharing responsibilities and being accountable for one's actions. This should be the goal of all organisations; nothing less should be acceptable. A fundamental reason for shifting employees from dependence to independence is to improve bottom-line indicators, such as productivity and quality, while the worker benefits as well. Clearly, this would not be possible unless every employee was considered a true self-leader. Also, a work environment needs to be enthused by a satisfied and emotionally contented workforce where rewards are intrinsic and the benefits are there for all to see in the guise of a happy and committed staff. The results of the empirical investigation confirm that there is a significant relationship between the job satisfaction of workers and their leader's perceived EI in a collegial environment. This also means that the more satisfied workers are, the more appropriate and meaningful would be their leader's social skills to demonstrate emotionally intelligent behaviours in a collegial work environment. This being an exploratory study means that more research needs to be done on this subject. 


\section{AUTHOR INFORMATION}

Professor Prakash Singh is a professor of education at the Nelson Mandela Metropolitan University in Port Elizabeth, South Africa. He is currently a rated researcher by the National Research Foundation in South Africa and is a former Senior Research Fulbright scholar. Professor Singh is the author of Innovative Strategies to Develop Better Schools. He has also published widely in peer-reviewed journals, focusing on leadership and management, organisational effectiveness, emotional intelligence, tobephobia, and curriculum development. Professor Singh has presented numerous papers at international conferences. E-mail: Prakash.Singh@nmmu.ac.za

\section{REFERENCES}

1. Ashkanasy, N. \& Dasborough, M. (2003). Emotional awareness and emotional intelligence in leadership teaching. Journal of Education for Business, 79:18-22.

2. Bar-On, R. (2000). Handbook of emotional intelligence. San Francisco: Jossey Bass.

3. Barth, S.R. (2006). Improving relationships within the schoolhouse. The Best of Educational Leadership 2005 - 2006: 29-33.

4. Burbach, M.E., Barbuto, J.R. \& Wheeler, D.W. (2003). Linking an ability model of emotional intelligence to transformational leadership behaviours. University of Nebraska: Lincoln.

5. Bush, T. (2003). Organisational structure. In M.Thurlow, T. Bush \& M. Coleman M (Eds.), Leadership and strategic management in South African organisations. London: Commonwealth Secretariat.

6. Calitz, L. (2002). Leadership for change in education: The South African perspective. In L. Calitz, O.L. Fuglestad \& S. Lillejord (Eds.), Leadership in Education. Sandown: Heineman.

7. Caruso, D. (1999). Multifactor emotional intelligence. New York: Basic Books.

8. Caruso, D. \& Salovey, P. (2003). The emotionally intelligent manager. San Fransisco: Jossey-Bass.

9. Cherniss, C. (2000). Social and emotional competence in the workplace. In R. Bar-On \& J.D.A Parker (Eds.), The handbook of emotional intelligence. San Francisco: Jossey-Bass.

10. Cooper, R. \& Sawaf, A. (1997). Executive EQ. emotional intelligence in business. London: Texere.

11. Covey, S. R. (2004). The eighth habit. Sydney: Simon \& Schuster.

12. Day, C. (2000). Effective leadership and reflective practice. Educational Leadership, 1, 113-127.

13. Elmore, R. (2000). Leadership for effective middle school practice. Phi Delta Kappan, 82, 269-270.

14. Fehd, L. 2001. Emotional intelligence: An executive handbook. Austin: Good Pages.

15. Gardiner, L. \& Stough, C. (2002). Examining the relationship between leadership and emotional intelligence in senior level managers. Leadership and Organisation Development Journal, 23, 68-78.

16. Garmston, R.J. \& Wellman, B.N. (Eds.). (1995). The adaptive school: Leading and facilitating collaborative work culture. Norwood: Christopher Gordon.

17. Gaziel, H. (2003). Images of leadership and their effect upon school principals' performance. International Review of Education, 49, 475-486.

18. Gazzard, A. (2002). Emotional intelligence, the witness and education. Encounter, 15, 20-29.

19. Goleman, D. (1996). Emotional intelligence. London: Bloomsbury.

20. Goleman, D. (1998). Working with emotional intelligence. New York: Bantam Books.

21.

22.

Goleman, D. (2004). Emotional intelligence \& working with emotional intelligence. London: Bloomsbury. Hellriegel, D., Jackson, S.E., Slocum, J., Staude, G., Amos, T., Klopper, H.B., Louw, L. \& Oosthuizen, T. (2006). Management. Oxford: Cape Town.

23. Hilliard, V.G. (1995). Performance improvement in the public sector. Pretoria: Van Schaik.

24. Huysamen, G.K. (1997). Descriptive statistics for the social and behavioural sciences. Cape Town: Creda.

25. Ihara, C.K. (1998). Professional ideals. California: Wadsworth.

26. Johns, G. (1996). Organisational behaviour. Understanding and managing life at work. New York: Harper.

27. Khol, R. (2004). How to be a good manager. Machine Design, 76, 12-13.

28. Kouzes, J.M. \& Posner, B.Z. (1995). The leadership challenge. San Fransisco: Jossey-Bass.

29. Kouzes, J.M. \& Posner, B.Z. (1997). The leadership challenge. San Francisco: Jossey-Bass.

30. Kouzes, J.M. \& Posner, B.Z. (2001). Bringing leadership lessons from the past into the future. In W. Bennis, G.M. Spreitzer \& T.G.Cummings (Eds.), The future of leadership. San Francisco: Jossey-Bass.

31. Landy, F.G. (1985). Psychology of work behaviour. Illinois: Homewood. 
32. Lee, Q. (2005). Leadership levels and issues. Lean Briefing Newsletter. Retrieved from: www.strategosinc.com/leadership

33. Lethoko, M. (2004). The role of teachers in the culture of learning and teaching. In L. Calitz, O.L. Fuglestad \& S. Lillejord (Eds.), Leadership in Education. Sandown: Heineman.

34. Maile, S. (2000). Recognition of competence: An empowerment model for the retention of excellent teachers in the classroom. Unpublished PhD thesis. Pretoria: University of Pretoria.

35. Manser, P.G. (2005). The influence of school principals' emotionally intelligent behaviours on the job satisfaction of teachers in the Eastern Cape. Unpublished PhD thesis. Port Elizabeth: Nelson Mandela Metropolitan University.

36. Maryl, C., Hardin, F., Olibas, L., Rodgers, T. \& Spiller, K. (2004). Case study of characteristics of effective leadership in graduate student collaborative work. Education, 124, 721-728.

37. Manz, C.C. \& Sims, H.P. (2001). The new super leadership. San Francisco: Berrett-Koehler.

38. McCann, J. (2000). Wanted: A reality check. Community College Week 12, 4.

39. McMillan, J.H. \& Schumacher, S. (2001). Research in education. New York: Longman.

40. Merkowitz, R.F. \& Earnest, G.W. (2006). Emotional intelligence: a pathway to self-understanding and improved leadership capacities. Retrieved from: http://www.joe.org/joe/2006august/iw3.shtml

41. Mertler, C.A. (2002). Job satisfaction and perception of motivation among middle and high school teachers. American Secondary Education, 31:43-44.

42. Middlewood, D. (2003). Managing teacher performance and its appraisal. In J. Lumby, D. Middlewood \& E. Kaabwe (Eds.), Managing human resources in South African schools. Huddersfield: The Commonwealth Secretariat.

43. Millinger, C.S. (2004). Helping new workers cope. Educational Leadership, 61, 66-73.

44. Moller, T. (2002). The influence of emotional intelligence on management with special reference to leaders of schools. In: L. Calitz, O.L. Fuglestad \& S. Lillejord (Eds.), Leadership in Education. Sandown: Heineman.

45. Northouse, P.G. (2004). Leadership: theory and practice. London: Sage.

46. Orme, G. \& Bar-On, R. 2002. The contribution of emotional intelligence to individual and organisational effectiveness. Competency and Emotional Intelligence, 9, 23-28.

47. Pauw, J.G. \& Kok, J.C. (2002). Onderwysdoelstellings en die ontwikkeling van menslike potentiaal. South African Journal of Education, 22, 6-9.

48. Propenko, J. (1987). Productivity management: A practical handbook. Geneva: ILO.

49. Reichheld, F. (2001). Leadership for loyalty. Harvard Business Review, 79, 4.

50. Retallick, J. \& Fink, D. (2002). Framing leadership: Contributions and impediments to educational change. International Journal of Leadership in Education, 5(20): 91-104.

51. Robson, C. (2002). Real world research: a resource for social scientists and practitioner-researchers. Oxford: Blackwell.

52. Sergiovanni, T.J. (1991). The leadership: a reflective practice perspective. Boston: Allyn and Bacon.

53. Singh, P. (2005). Use of the collegial leadership model of emancipation to transform traditional management practices in secondary schools. South African Journal of Education, 25(1):11-18.

54. Singh, P. (2008). Emotional intelligence begets collegial leadership in education. The International Journal of Learning, 15(1), 73-88.

55. Singh, P. \& Manser, P. (2002). Collegiality in education: a case study. South African Journal of Education, 22(1), 56-64.

56. Singh, P. \& Manser, P. (2008). Correlation between the perceived emotionally intelligent interpersonal behaviors of school principals and the job satisfaction of their teachers. The International Journal of Knowledge, Culture \& Change Management, 8(1), 189-200.

57. Stahl, D. (2000). What do employees expect of leaders? Nursing Management, 31, 58-59.

58. Stein, S. \& Book, H. (1999). The EQ edge. Emotional intelligence and your success. Kogan Page.

59. Sterrett, E. A. (2000). The manager's pocket guide to emotional intelligence. Massachusetts: HRD Press.

60. Strümpfer, D. J. W. \& Mlonzi, E. N. (2001). Antonovsky's sense of coherence scale and job attitudes: three studies. South African Journal of Psychology, 31, 31-54.

61. Vermeulen, S. (1999). EQ. Emotional intelligence for everyone. Rivonia: Zebra Press.

62. Wasserstein-Warnet, M. M. (2000). Principals' cognitive strategies for changes of perspective in school innovation. School Leadership and Management, 20, 435-457. 
63. Weber, B. (2004). Leadership: Do you have the motivation? Plastic Surgical Nursing, 24, 91.

64. Whitaker, P. (2001). Managing to learn. London: Cassell.

65. Williams, K. (1989). The case for democratic management in schools. Irish Education Studies.

66. Yukl, G. (1998). Leadership in organisations. Saddle River: Prentice Hall.

67. Yun, W. (1998). Successful employee motivation in China. Alta Vista: Regional Centre of Ngee Ann Polytechnic. 